\title{
Why Brazil needs an umbrella urgently: about the challenges of public health model of palliative care and the use of available resources
}

Keywords: public health, primary care, palliative care, family health strategy

\section{"Opportunities multiply as they are seized." - Sun Tzu}

Brazil faces many challenges in palliative care. Recognizing the strengths, weaknesses, obstacles, and opportunities in the Health System of that country can generate a better future for the percentage of the population that does not have access to palliative care. One of the recognized weaknesses is the lack of a public health approach to answer the growing demand for palliative care ${ }^{1}$. This text proposes an evaluation of the four components of a model published by World Health Organization (WHO) in $1990^{2}$, and which is the actual situation today. This paper will also analyze some of strengths, weaknesses, obstacles, and opportunities to further develop this model ${ }^{3}$.

\section{Policy}

Brazil has good professional staff with palliative care expertise distributed in various groups around the country. However, while interest in palliative care is growing given the increasing number of articles, congresses, and other events discussing the subject, it is not substantially reflected in public policies as a priority or public health matter.

Since WHO published its Public Health Model in $1990^{2}$, the Brazilian Ministry of Health has released some official documents concerning palliative care both specifically and as part of other policies, though without reflecting on a public health policy $y^{4,5}$. Equally, most chronic condition guidelines published by the Ministry of Health do not quote palliative care as a possibility, and even when they do, it relates more to specific situations, such as cancer and homecare ${ }^{6}$.

There is no specific funding for palliative care provided by the Brazilian National Health System, and the proposed indicators for palliative care by the National Institute of $\mathrm{Cancer}^{7}$ are not largely applied to public health. Brazil does not have a specific patient register linking palliative care to public health either; as an example of what does exist, the National Health System's registry for primary care $^{8}$ does not have a space to indicate palliative care for eligible diseases, nor those diseases' International Code of Diseases (ICD). The choice of ICD-10-CM for palliative care (Z51.5) is allowed, but poorly discussed and encouraged to be used.

Brazil mainly provides palliative care in hospitals, though there is a document from the Ministry of Health that presents the idea of it, among other treatments, in a homecare setting 9 . There is not a specific agenda or program for palliative care from the National Program of Primary Care called Family Health Strategy, despite its 43,000 active teams distributed around the country ${ }^{10}$ covering over $60 \%$ of the population (around 168 million). Very few community centers provide systematic palliative care, too ${ }^{11}$, and there is no integrated network that supports and follows patients when identified as needing palliative care figure 1 .

\author{
Volume 2 Issue 4 - 2018 \\ Santiago Rodríguez Corrêa,' Carla Mazuko ${ }^{2}$ \\ 'Family Physician, MSc on Medical Sciences Project Estar ao Seu \\ Lado- Cuidados Paliativos na Atenção Primária, Rio Grande, \\ Brazil; Honorary Research Associate, School of Interdisciplinary \\ Studies, University of Glasgow, Scotland \\ ${ }^{2}$ Nurse, Master Degree in Nursing, Project Estar ao Seu Lado- \\ Cuidados Paliativos na Atenção Primária, Rio Grande, Brazil
}

\author{
Correspondence: Santiago Rodríguez Corrêa, Family \\ Physician, MSc on Medical Sciences Project Estar ao Seu \\ Lado- Cuidados Paliativos na Atenção Primária, Rio Grande, \\ Brazil; Honorary Research Associate, School of Interdisciplinary \\ Studies, University of Glasgow, Scotland,
}

Email santiagorcorrea@yahoo.com.br

Received: July 16, 2018 | Published: August 22, 2018

\section{Drug availability}

Opioids and some medicines listed as essential by $\mathrm{WHO}^{12}$ are part of the national list of medicines provided by the Brazilian government ${ }^{13}$. However, access to opioids is limited due to prescription regulations instated by The Brazilian Health Regulatory Agency (Anvisa), with morphine use estimated at just $3.09 \mathrm{mg} / \mathrm{per}$ capita in $2015^{14}$. Related, the limited use of stronger opioids crosses all levels of attention. Brazil does not have a specific program that educates about and supports the use of stronger opioids, just like some African countries. However, a Brazilian primary physician can prescribe this kind of medicine. Regulations, misconceptions, professionals' lack of information about pain control, and palliative care could explain this low opioid consumption.

\section{Education}

The lack of formal education about palliative care and related themes is other great obstacle to overcome in Brazil. In 2013, just two of all the Brazilian medical schools offered a formal program on palliative care ${ }^{15}$. Vacancies in formal post-graduate palliative medicine courses are very low as well, far from the amount necessary to help patients with complex needs. The recognition of palliative medicine as a specialty just opened in 2016 .

The same lack of formal courses or discussion about palliative care crosses all post-graduate medical specialties, perhaps contributing to the undeveloped systematic palliative care in Brazilian primary care and community centers ${ }^{1}$. This certainly prevents the identification and following of patients who require a different approach in the end of their life with costs to both their quality of life and the National Health System.

Despite a recent rise in media discussion about death and dying subjects, palliative care awareness at the community level is still low ${ }^{16}$. Themes surrounding death and dying are not commonly present 
in community awareness or projects, which could ignite interest or discussion about palliative care. In fact that discussion seems to be restricted to the "professional world," which excludes Brazil as it has not utilized local communities as a tool, partner, or care provider. This inactivity contradicts the compassionate community international documents and practice examples that exist abroad. ${ }^{17}$

\section{Policy}

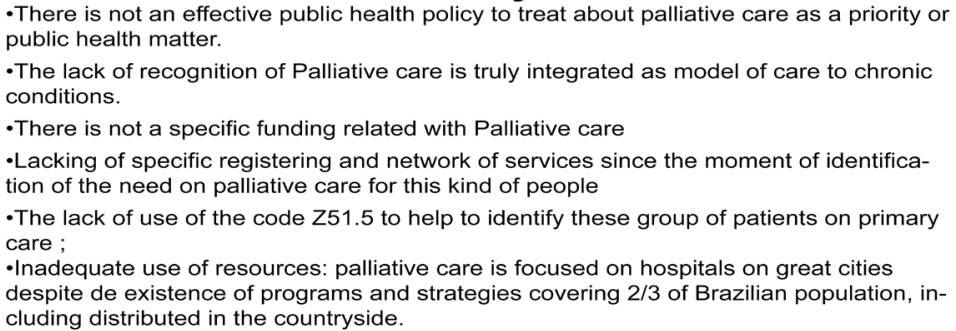

\section{Education}

-The lack of a formal curriculum about palliative care and all themes of end of life care as well in gradu-The number of vacancies of formal post graduation courses on palliative medicine is very low. -Palliative care as well other death and dying subjects seems to be related with "professional world" - Few projects related with commu-Few projects related with commutential of community as tool, a partnership or source of care;

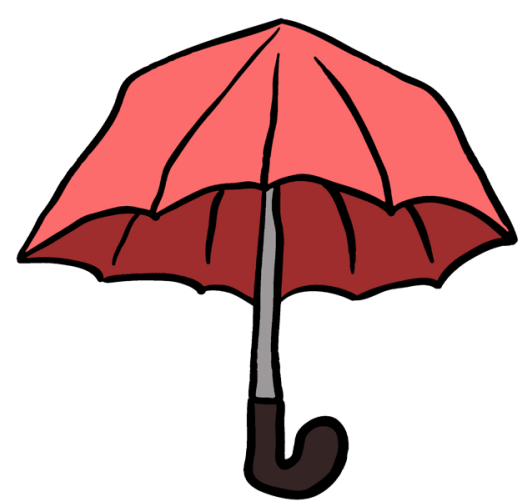

Implementation

-The discussion about palliative care in Brazil is almost totally focused on content and the continent is hardly discussed. - Congresses themes are biased to specific symptoms and complex situations and the discussion of settings is focused in Hospitals and Intensive Care. - Lacking of a continue translation of knowledge from the Brazilian leaders on palliative care to professional linked with community.

-The effects of main internationa documents and proposals were not already felt in Brazil.

\section{Drug Availability}

- Despite some medicines and some opioids are provided by the National List of Medicines the access is very hard. -Consumption of Morphine is very low$3,09 \mathrm{mg} /$ per capita.

Figure I Adapted of the WHO public health model

\section{Implementation}

Leading staff of palliative care are working hard to share its benefits in Brazil. However, the discussions and programs about palliative care are more focused on patient, family, and bed without a balanced necessary discussion on public health, community aspects, and broader aspects of care. Congressional debates turn to specific symptoms and complex situations, which are less statistically feasible for the whole population. The same situation reflects in discussions that focus on settings like intensive care units without a balance to cover the "macro palliative care" with a public health concern.

Stjernsward $\mathrm{J}$, et al. mentioned, it is necessary for leaders of palliative care to translate their knowledge to both communities and the professionals linked to those communities to provide a sustainable system and care network. It is necessary to balance between these two groups in seeking the benefit of more people, without complex needs. ${ }^{17}$

WHO's 2014 report defended the implementation and integration of palliative care through all levels of care, diseases, and settings ${ }^{18}$, but until this moment the effects of that document were not clear in Brazilian academic palliative care institutions and government programs. The country needs to listen to the voices from abroad and start a new age of palliative care.

\section{The desired outcome: a new public health strategy}

However these four domains of the WHO model are assessed to explain the challenges and difficult situations in Brazilian palliative care, they are linked in reality. As pointed above deep changes in all four domains are necessary to provide palliative care to most of the population.

The rational use of existing programs and resources to identify patients with palliative care needs can begin this care model as the first step of a long journey. The number of pertinent patients with palliative needs probably is bigger than the common estimates and most of them are living just in territory covered by the Family Health Strategy), the primary care program that covers more than 160 million of people in Brazil. A substantial part of the population lives in extreme poverty (around $6 \%$ of all population) with difficult or delayed access to the treatment of certain diseases. The use of the health programs of the government will permit an estimated demand 
of basic needs, complex needs, and the specialists to supply them; costs and necessary resources for the health system; and strategies to reach immediate, intermediate, and long-term outcomes.

Brazil needs big efforts and changes to have its public health strategy It is time for both institutions and community and government professionals, at all levels, to change the palliative care discussion. Together, they can create solutions that improve its access, education, and implementation, as well as build a sustainable care policy that benefits the population as a whole. To reach these objectives Brazil will need of a commitment from everyone.

\section{Acknowledgements}

None.

\section{Conflict of interest}

The author declares no conflict of interest.

\section{References}

1. Corrêa SR, Mazuko C, Floss M, et al. Brazil: time for palliative care in the community! Eur J Palliat Care. 2016;23(2):94-96

2. World Health Organization. Cancer pain relief and palliative care. Technical report series 804, Geneva: World Health Organization; 1990.

3. Stjernsward J, Foley KM, Ferris FD. The public health strategy for palliative care. J Pain Symptom Manage. 2007;33(5):486-493.

4. PORTARIA No $2.439 / \mathrm{GM}$ DE 8 DE DEZEMBRO DE 2005. Institui a Política Nacional de Atenção Oncológica: Promoção, Prevenção, Diagnóstico, Tratamento, Reabilitação e Cuidados Paliativos, a ser implantada em todas as unidades federadas, respeitadas as competências das três esferas de gestão. Brasil: Ministério da Saúde; 2005

5. PORTARIA No 874, DE 16 DE MAIO DE 2013. Institui a Política Nacional para a Prevenção e Controle do Câncer na Rede de Atenção à Saúde das Pessoas com Doenças Crônicas no âmbito do Sistema Único de Saúde (SUS). Brasil: Ministério da Saúde; 2013.

6. Secretaria de Vigilância em Saúde. Departamento de Análise de Situação de Saúde. Plano de ações estratégicas para o enfrentamento das doenças crônicas não transmissíveis (DCNT) no Brasil 2011-2022. Brasil Ministério da Saúde; 2011. p. 1-154;
7. Instituto Nacional de Câncer. Indicadores da unidade de cuidados paliativos: hospital do câncer IV do Instituto Nacional de Câncer 2009. Brasil: Ministério da Saúde; 2009.

8. E-sus Atenção Básica. Brasil: Ministério da Saúde.

9. Secretaria de Atenção à Saúde. Departamento de Atenção Básica. Caderno de atenção domiciliar. Brasil: Ministério da Saúde; 2013. p. $7-204$.

10. Departamento de Atenção Básica. Brasil: Ministério da Saúde;

11. Corrêa SR, Mazuko C, Mitchell G, Pastrana T, De Lima L, Murray SA. Identifying patients for palliative care in primary care in Brazil: Project Estar ao Seu Lado's experience. Rev Bras Med Fam Comunidade. 2017;12(39):1-8.

12. World Health Organization. Essential Medicines in Palliative Care. 2013.

13. Brasil. Ministério da Saúde. Relação Nacional de Medicamentos Essenciais.

14. Pain and Policy Studies Group. Opioid Consumption Data. AMRO OPIOID CONsumption; 2015.

15. Figueiredo MdGMCdA, Stano RdCMT. O estudo da morte e dos cuidados paliativos: uma experiência didática no currículo de medicina [The study of death and palliative care: a teaching experience in the undergraduate medicine curriculum]. Revista Brasileira de Educação Médica. 2013;37:298-307.

16. The Economist and Intelligence Unit. The 2015 quality of death-ranking end-of-life care across the world. 2015

17. Abel J, Walter T, Carey LB, et al. Circles of care: should community development redefine the practice of palliative care? BMJ Supportive \& Palliative Care. 2012;3(4).

18. 67th World Health Assembly resolution WHA67.19. Strengthening of palliative care as a component of comprehensive care throughout the life course. 2014 